\title{
The Relationship between the Methylation of Promoter Regions of Tumor Suppressor Genes PTEN and $A P C$ with Endometrial Cancer
}

\author{
Tayebeh Ghazanfari, Golnaz Asaadi Tehrani*, Parisa Maziri
}

\begin{abstract}
Background: Endometrial neoplasms is one of the most typical gynecologic diseases with harmful effects. Promoter hypermethylation is an important mechanism of the inactivation of tumor suppressor genes in endometrial neoplasms. Epigenetic changes of the PTEN and $A P C$ genes have shown to be present in various cancers. Therefore, in this study, we have investigated the association between the promoter hypermethylation of PTEN and $A P C$ genes with endometrial neoplasms. Methods: For this study, 28 patients with endometrial neoplasms as well as 22 controls were studied. Analysis of the promoter methylation regions of PTEN and APC genes were performed by Methylation-Specific PCR. Results: The frequency of PTEN and $A P C$ genes promoter methylation was $28.57 \%$ and $17.86 \%$ in tumor tissues, and $11.54 \%$ and $3.85 \%$ in blood samples, respectively. We found a significant relationship between blood and tissue in PTEN methylation $(\mathrm{p}=0.0353)$. Additionally, we determined a closely significant difference between normal tissue and tumor tissue of the PTEN gene $(\mathrm{p}=0.0787)$ and blood and tissue samples of the $A P C$ gene in methylated promoter regions $(\mathrm{p}=0.0623)$. Furthermore, these results suggest that there is no significant relationship between the promoter methylation of PTEN and APC with clinical characteristics. Conclusion: DNA methylation deficiency is a well known highlighted factor in tumorigenesis, therefore the promoter hypermethylation of PTEN and $A P C$ can be indicated as a risk factor in endometrial neoplasms.
\end{abstract}

Keywords: Endometrial neoplasms, DNA methylation- APC-PTEN

Asian Pac J Cancer Prev, 20 (8), 2259-2265

\section{Introduction}

One of the most common forms of cancers in females, which is usually recognized at early stages, is endometrial cancer (EC) (Markowska et al., 2014). Collected information has revealed that the prevalence of endometrial cancer with stage I and II was $73 \%$ and $10 \%$, respectively (Trimble et al., 2005; Creasman et al., 2006). There are two variants of endometrial cancer with diversity in their clinicopathologic features. Type I tumors (endometrioid caners) are completely differentiated and estrogen-related. On the other hand, type II tumors (non-endometrioid cancers) are non-estrogen-related (Tao and Freudenheim, 2010). Major risk factors in endometrial cancer include the estrogen element, mismatch repair disorders, microsatellite instability, and epigenetic variation (Banno et al., 2014; Mutter et al., 1996). Similar to other types of cancer, endometrial carcinoma can be caused by the aggregation of genetic mutations (Feng et al., 2012).

Genomic DNA methylation depends on the addition of methyl groups at $\mathrm{CpG}$ sites by DNA methyltransferase.
DNA methylation is normally visible in promoters and is important for gene expression (Muraki et al., 2009). The inactivation of tumor suppressor genes is one of the reasons of tumor formation (Herman and Baylin, 2003). Phosphatase and tensin homologue (PTEN) is a type of tumor suppressor gene that is in $10 q 23.31$. It is vital for the inhibition of cell migration. PTEN is a type of lipid 3-phosphatase and can moderate different types of cell-survival pathways (Waite and Eng, 2002). The $\mathrm{PI} 3 \mathrm{~K}-\mathrm{AKT}$ pathway is negatively regulated by the PTEN protein. 34-55\% of endometrial cancers are reported with mutations in PTEN (Risinger et al., 1997; Kong et al., 1997). The inactivation of PTEN in endometrial cancer could be investigated by promoter hypermethylation, instability of the protein, and a change in the regulation of the gene (Zhang and Yu, 2010). Many surveys have reported that $20 \%$ of type I endometrial cancers are methylated in the promoter region of the PTEN and APC genes (Macdonald et al., 2004; Salvesen et al., 2001). PTEN is a second messenger of phosphatidylinositol 3-kinase (PI3K) that negatively regulates serine/ threonine kinase Akt. The phosphorylation of Akt modifies the 
activities of many downstream proteins that regulate the growth of cells and inhibit apoptosis (Oda et al., 2005; Velasco et al., 2006; Dubrovska et al., 2009; Rychahou et al., 2008).

The adenomatous polyposis coli $(A P C)$ is a tumor suppressor gene that is located in 5q21-22 (Aoki and Taketo, 2007). Alterations of the $A P C$ gene has been reported in $80 \%$ of colon cancers (Powell et al., 1992; Nagase and Nakamura, 1993). The Wnt pathway is regulated by mutations in the $A P C$ and $\beta$-catenin genes that are also correlated with endometrial cancer (Schlosshauer et al., 2000; Kobayashi et al., 1999). Hypermethylation of the APC promoter has been reported in $20-45 \%$ of endometrial cancers (Banno et al., 2006; Yang et al., 2006). $A P C$ is shown to moderate $\beta$-catenin levels, whereas, inhibition of $A P C$ expression will lead to an increase in the levels of $\beta$-catenin, which induces the Wnt signaling pathway and eventually increases the transcriptional activity (Fearnhead et al., 2001; Behrens et al., 1996). The purpose of the present study is to evaluate the association between $P T E N$ and $A P C$ promoter hypermethylation with endometrial cancer in the blood and tissue samples in endometrial cancer patients. Also, we aim to investigate the correlation between endometrial cancer and distinct clinical characteristics.

\section{Materials and Methods}

\section{Research population}

Twenty eight cancerous tissues along with associated clinopathological parameters and twenty six blood samples of the same individual with endometrial cancer were collected from patients who had been referred to the Mahdiyeh Hospital (Tehran, Iran), Firuzgar Hospital (Tehran, Iran), Kowsar Hospital (Ghazvin, Iran), and Pastour Hospital (Ghazvin, Iran), between 2014 and 2016. In addition, twenty-two normal tissues were sampled as the control group. Informed consent was signed by the patients. The average age was 65.5 years for both groups (range, 38-76 years). None of the patients had received chemotherapy. They were examined in the Biology Research Center of Islamic Azad University, Zanjan (Iran). The clinical diagnosis of endometrial cancer was in accordance with the criteria of the International Federation of Gynecology and Obstetrics (FIGO). The clinicopathologic traits were diagnosed by experted gynecologists.

\section{DNA isolation and methylation-specific PCR}

Tissue samples were cut into $10 \mu \mathrm{m}$ segments and used for DNA isolation (Cat.NO.180134, QIAGEN Inc, Valencia, CA) and also genomic DNA was extracted from EDTA-blood samples using the cinnaClon Genomic DNA purification Kit (Cat.No.PR881612) following the manufacturer's instructions. Sodium bisulfite converts unmethylated cytosine to uracil. The effects of bisulfite were performed by the CpG genome DNA Modification Kit (Cat.No.59104, QIAGEN Inc, Valencia, CA) (Yari et al., 2016). Afterwards, the buffer BL/carrier RNA solution was used to increase extracted DNA levels (Cat. No.59104, QIAGEN Inc, Valencia, CA ) (Gravina et al., 2015). Forward and reverse primers were designed for unmethylated and methylated promoter regions by Gene runner and meth primer software after obtaining gene sequences from Gene Bank (http://www.ncbi.nlm. nih.gov). The primer sequences are shown in Table 1. Amplification was carried by gradient PCR, using a model of PCR gradient thermo cycler (Eppendorf, Germany). MSP amplification was performed in a final volume of $20 \mu \mathrm{L}$ containing 1X PCR Master Mix (CinnaGen PCR Master Mix, Iran), $50 \mathrm{ng}$ of template bisulfite converted DNA, and 10 pmol of forward and reverse primers each (Gen Fanavaran, Iran). MSP amplifications was performed as follows: the first denaturation cycle of DNA at $95^{\circ} \mathrm{C}$ for $5 \mathrm{~min}$ followed by 34 cycles, each consisting of $45 \mathrm{~s}$ denaturation at $95^{\circ} \mathrm{C}, 45 \mathrm{~s}$ annealing at $59^{\circ} \mathrm{C}$ for $P T E N$ (M), $57^{\circ} \mathrm{C}$ for PTEN (U), $54^{\circ} \mathrm{C}$ for $A P C(\mathrm{M}), 57^{\circ} \mathrm{C}$ for $A P C(\mathrm{U})$, and $45 \mathrm{~s}$ extension at $72^{\circ} \mathrm{C}$, with the final extension cycle of $72^{\circ} \mathrm{C}$ for $5 \mathrm{~min}$. The PCR products were analyzed by the electrophoresis of agarose gel $(2.5 \%$ agarose), stained with DNA safe stain and visualized by a UV transilluminator. For MSP confirmation and correct determination of methylated, hemimethilated, and non methylated genotypes, modified genomic DNA samples from regulatory $\mathrm{CpG}$ islands of both normal endometrium and cancerous tissue were analyzed by sequencing for both $P T E N$ and $A P C$ genes.

\section{Statistical analysis}

The statistical comparison was calculated by Pearson's chi-square. The data analysis was performed by SPSS20. P-values $<0.05$ were statistically significant. The rates of odds ratio and $95 \%$ confidence intervals were assayed by logistic regression.

\section{Results}

\section{Determination of clinicopathological features}

The samples consisted of 25 endometrioid carcinomas [endometrial adenocarcinoma:19 FIGO grade 1 (stage IA, IB), 4 FIGO grade 2, 2 FIGO grade 3 (IIIB)], and 3 nonendometrioid carcinomas [serous papillary :3 FIGO grade 3 (stage IIIA)]. Nine of twenty-five (36\%) endometrioid carcinomas showed metastasis. In addition, nonendometrioid carcinomas lacked signs of any metastasis.

Analysis of promoter methylation in PTEN and APC genes Methylation specific PCR was used to assay the role of the methylation status of PTEN and APC promoters in endometrial cancer. The frequencies of PTEN and $A P C$ methylation in promoter regions have been shown in Table 2. Hypermethylation of PTEN was observed in $28.57 \%$ of tumor tissues and $4.54 \%$ of normal tissues (Figure 1, 3). The results were closely linked to being statistically significant between tumor tissues and normal tissues (OR=2.0765, 95\% CI [0.9197-4.6887], $\mathrm{p}=0.0787$ ) (Table 2). There was a significant increase of PTEN methylation in patients' blood (11.54\%) compared to tumor tissues $(28.57 \%)$. There was a significant difference in the methylation of the PTEN promoter between the patients' blood and tumor tissues (OR=2.4377, 95\% CI [1.06355.5876], $\mathrm{p}=0.0353$ ) (Table 2). Promoter methylation 
Table 1. Primer Pairs Used for Methylation-Specific PCR

\begin{tabular}{llc}
\hline Primer & Primer sequence $\left(5^{\prime}-3^{\prime}\right)$ & Size $(\mathrm{bp})$ \\
\hline PTEN promoter methylated (M) & F:GGT TTC GGA GGT CGT CGGC & 19 \\
& R:CAA CCG AAT ATT AAC TAC TAC GAC & 24 \\
PTEN promoter unmethylated (U) & F:TGG GTT TTG GAG GTT GTT GGT & 21 \\
APC promoter methylated (M) & R:ACT TAA CTC TAA ACC ACA ACC & 21 \\
APC promoter unmethylated (U) & F:TAT TGC GGA GTT CGG GTC & 18 \\
& R:TCG ACG AAC TCC CGA CGA & 18 \\
\hline
\end{tabular}

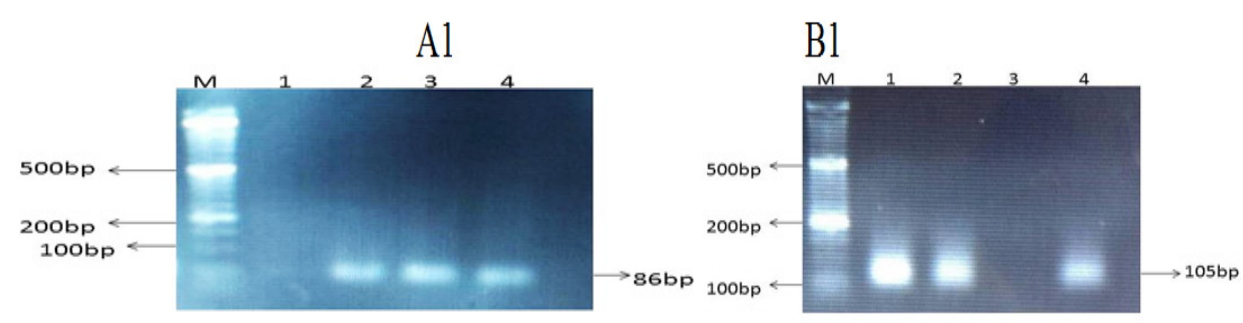

Figure 1. Methylation-Specific PCR Analysis of PTEN Promoter: A1: using unmethylated promoter primers; Lane M: 50bp ladder; Lane 1: absence of $P C R$ products: methylated promoter; Lanes 2, 3, 4:unmethylated $P C R$ products (86bp). B1: using methylated promoter primers; Lane M: 50bp ladder; Lanes 1, 2, 4: methylated $P C R$ products (105bp); Lane 3: absence of $P C R$ products: unmethylated $P C R$ products.

was shown in the $A P C$ gene in $17.86 \%$ of tumor tissues and $4.55 \%$ of normal tissues (Figure 2, 3). The study showed that $A P C$ methylation was not significantly correlated between tumor tissues and normal tissues $(\mathrm{OR}=0.7073,95 \%$ CI $[0.2995-1.6703], \mathrm{p}=0.4296)($ Table 2). Among the patients' blood, the frequency of promoter methylation in the $A P C$ gene was $3.85 \%$ (Figure 2, 3). Results indicate that the promoter methylation analysis of the APC gene between tumor tissues and patients' blood is statistically significant $(\mathrm{OR}=0.4047,95 \% \mathrm{CI}$ [0.1563-1.0476] , $\mathrm{p}=0.0623$ ) (Table 2). The association between the methylation of PTEN and APC promoters with clinicopathological features was analyzed in the endometrial cancer. We found no significant correlations between clinicopathological features, including age, tumor grade, tumor stage, histologic type, depth of myometrial
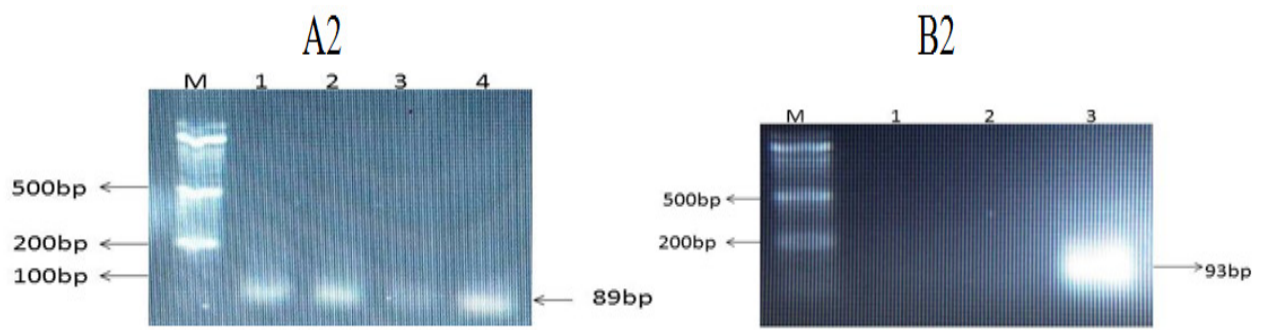

Figure 2. Methylation-Specific PCR Analysis of $A P C$ Promoter: A2: using unmethylated promoter primers ; Lane M: $50 \mathrm{bp}$ ladder; Lanes 1,2, 3, 4:unmethylated $P C R$ products $(89 \mathrm{bp})$. B2: using methylated promoter primers ; Lane M: $50 \mathrm{bp}$ ladder; Lanes 1, 2: absence of $P C R$ products: unmethylated $P C R$ products; Lane 3: methylated $P C R$ products $(93 \mathrm{bp})$.

Table 2.The Methylation Status of the Promoter Region of PTEN and APC Genes in the Study Population

\begin{tabular}{lccccccc}
\hline Gene & $\begin{array}{c}\text { Study population } \\
\text { (number) }\end{array}$ & $\begin{array}{c}\text { Methlyted } \\
\text { number (\%) }\end{array}$ & $\begin{array}{c}\text { Hemi-methlyted } \\
\text { number (\%) }\end{array}$ & $\begin{array}{c}\text { Non-methlyted } \\
\text { number (\%) }\end{array}$ & OR & 95\%CI & P-value \\
\hline PTEN & Normal tissues (22) & $1(4.54 \%)$ & $13(59.10 \%)$ & $8(36.36 \%)$ & & & \\
& Tumor tissues (28) & $8(28.57 \%)$ & $13(46.43 \%)$ & $7(25 \%)$ & 2.0765 & $0.9197-4.6887$ & 0.0787 \\
& Patients' blood (26) & $3(11.54 \%)$ & $23(88.46 \%)$ & $0(0 \%)$ & 2.4377 & $1.0635-5.5876$ & 0.0353 \\
& & & & & & & \\
\multirow{2}{*}{$A P C$} & Normal tissues (22) & $1(4.55 \%)$ & $4(18.18 \%)$ & $17(77.27 \%)$ & & & \\
& Tumor tissues (28) & $5(17.86 \%)$ & $5(17.86 \%)$ & $18(64.28 \%)$ & 0.7073 & $0.2995-1.6703$ & 0.4296 \\
& Patients' blood (26) & $1(3.85 \%)$ & $7(26.92 \%)$ & $1(69.23 \%)$ & 0.4047 & $0.1563-1.0476$ & 0.0623 \\
\hline
\end{tabular}


Table 3. Relationship between PTEN and APC Promoter Methylation and Clinicopathological Features in Endometrial Carcinoma Patients

\begin{tabular}{|c|c|c|c|c|}
\hline \multirow[t]{3}{*}{ Parameters } & \multicolumn{2}{|c|}{ Blood samples } & \multicolumn{2}{|c|}{ Tissue samples } \\
\hline & \multicolumn{2}{|c|}{ Number of samples (\%) } & \multicolumn{2}{|c|}{ Number of samples (\%) } \\
\hline & PTEN & $A P C$ & PTEN & $A P C$ \\
\hline \multicolumn{5}{|l|}{ Total (tissue:n= 28, Blood: $\mathrm{n}=26$ ) } \\
\hline \multicolumn{5}{|l|}{ Age (yr) } \\
\hline$<50(4)$ & $2(40 \%)$ & $1(25 \%)$ & $1(25 \%)$ & $2(50 \%)$ \\
\hline \multirow[t]{2}{*}{$>50(24)$} & $12(57.1)$ & $3(14.3 \%)$ & $13(54.2)$ & $6(25 \%)$ \\
\hline & $\mathrm{p}=0.49$ & $\mathrm{P}=0.75$ & $\mathrm{p}=0.28$ & $\mathrm{p}=0.31$ \\
\hline \multicolumn{5}{|l|}{ Tumor grade } \\
\hline G1 (19) & $9(52.9 \%)$ & $3(17.6 \%)$ & $9(50 \%)$ & $3(16.7 \%)$ \\
\hline G2 (4) & $3(75 \%)$ & $1(25 \%)$ & $3(60 \%)$ & $2(40 \%)$ \\
\hline \multirow[t]{2}{*}{ G3 (5) } & $3(60 \%)$ & $1(20 \%)$ & $3(60 \%)$ & $1(25 \%)$ \\
\hline & $\mathrm{P}=0.72$ & $\mathrm{p}=0.95$ & $\mathrm{p}=0.88$ & $\mathrm{p}=0.53$ \\
\hline \multicolumn{5}{|l|}{ Tumor stage } \\
\hline IA (17) & $9(56.3 \%)$ & $4(25 \%)$ & $9(52.9 \%)$ & $3(17.6 \%)$ \\
\hline IB (2) & $1(50 \%)$ & $0(0 \%)$ & $0(0 \%)$ & $0(0 \%)$ \\
\hline II (4) & $2(66.7 \%)$ & $1(33.3 \%)$ & $2(50 \%)$ & $1(25 \%)$ \\
\hline IIIA (3) & $2(66.7 \%)$ & $1(33.3 \%)$ & $2(67 \%)$ & $2(67 \%)$ \\
\hline \multirow[t]{2}{*}{ IIIB (2) } & $2(100 \%)$ & $0(0 \%)$ & $2(100 \%)$ & $0(0 \%)$ \\
\hline & $\mathrm{P}=0.81$ & $\mathrm{p}=0.81$ & $\mathrm{p}=0.37$ & $\mathrm{p}=0.30$ \\
\hline \multicolumn{5}{|l|}{ Histologic type } \\
\hline Endometrioid type (25) & $13(56.5 \%)$ & $4(17.4 \%)$ & $13(52 \%)$ & $5(20 \%)$ \\
\hline \multirow[t]{2}{*}{ Nonendometrioid type (3) } & $2(66.7 \%)$ & $1(33.3 \%)$ & $2(66.7 \%)$ & $1(33.3 \%)$ \\
\hline & $\mathrm{p}=0.74$ & $\mathrm{p}=0.51$ & $\mathrm{p}=0.63$ & $\mathrm{p}=0.60$ \\
\hline \multicolumn{5}{|l|}{ Depth of myometrial invasion } \\
\hline Negative (3) & $2(66.7 \%)$ & $0(0 \%)$ & $2(66.7 \%)$ & $2(66.7 \%)$ \\
\hline$<50 \%(15)$ & $8(57.1 \%)$ & $3(21.4 \%)$ & $7(46.7 \%)$ & $2(13.3 \%)$ \\
\hline \multirow[t]{2}{*}{$>50 \%(10)$} & $6(66.7 \%)$ & $2(22.2 \%)$ & $5(50 \%)$ & $3(30 \%)$ \\
\hline & $\mathrm{P}=0.88$ & $\mathrm{p}=0.67$ & $\mathrm{p}=0.82$ & $\mathrm{p}=0.14$ \\
\hline \multicolumn{5}{|l|}{ Metastase } \\
\hline Negative (19) & $10(55.6 \%)$ & $4(22.2 \%)$ & $11(57.9 \%)$ & $4(21.1 \%)$ \\
\hline \multirow[t]{2}{*}{ Positive (9) } & $5(62.5 \%)$ & $1(12.5 \%)$ & $4(44.4 \%)$ & $2(22.2 \%)$ \\
\hline & $\mathrm{P}=0.74$ & $\mathrm{P}=0.56$ & $\mathrm{P}=0.50$ & $\mathrm{P}=0.94$ \\
\hline
\end{tabular}

invasion, and metastasis in endometrial cancer $(\mathrm{P}>0.05)$ (Table 3). In addition, the correlation between promoter hypermethylation of the PTEN and $A P C$ genes with clinical characteristics, including diabetes, high weight,

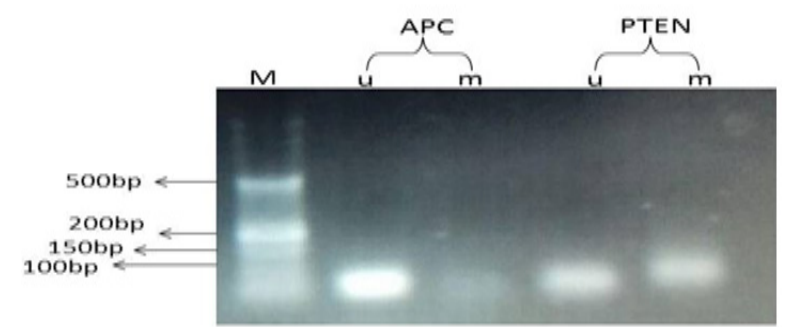

Figure 3. Methylation-Specific PCR Analysis of $A P C$ and PTEN Promoters: APC was unmethylated, PTEN was hemi-methylated; M, 50bp ladder ; u, reactions in unmethylated promoter primers; $m$, reactions in methylated promoter primers. high blood pressure, and menstrual disorder was evaluated. Results show there was no significant difference between clinical characteristics and promoter hypermethylation of the PTEN and APC genes in endometrial cancer $(\mathrm{P}>0.05)$ (Table 4).

\section{Discussion}

Aberrant DNA hypermethylation of tumor-suppressor genes is a prevalent molecular change in the early stages of cancers and it can be highlighted as a biomarker in the detection and treatment of tumors (laird., 2003). Epigenetic deficiencies with promoter hypermethylation have an important role in the inactivation of tumor suppressor genes in cancer (Salvesen et al., 2001). This study investigated the methylation of the promoter regions of the PTEN and $A P C$ genes in endometrial cancer. Considering circulating tumor cells are present 
DOI: 10.31557/APJCP.2019.20.8.2259

The Relationship between the Methylation of Promoter Regions of Tumor Suppressor Genes PTEN and APC

Table 4. Association between Clinical Characteristics of the Study Groups with Eendometrial Cancer

\begin{tabular}{|c|c|c|c|c|}
\hline \multirow[t]{3}{*}{ Parameters } & \multicolumn{2}{|c|}{ Blood samples } & \multicolumn{2}{|c|}{ Tissue samples } \\
\hline & \multicolumn{2}{|c|}{ Number of samples (\%) } & \multicolumn{2}{|c|}{ Number of samples (\%) } \\
\hline & PTEN & $A P C$ & PTEN & $A P C$ \\
\hline \multicolumn{5}{|l|}{ Diabetes } \\
\hline Negative (17) & $8(47 \%)$ & $4(23.5 \%)$ & $9(52.9 \%)$ & $4(23.5 \%)$ \\
\hline \multirow[t]{2}{*}{ Positive (11) } & $7(63.6 \%)$ & $2(18.2 \%)$ & $6(54.5 \%)$ & $2(18.2 \%)$ \\
\hline & $\mathrm{p}=0.390$ & $\mathrm{P}=0.736$ & $\mathrm{p}=0.934$ & $\mathrm{p}=0.736$ \\
\hline \multicolumn{5}{|l|}{ High weight } \\
\hline Negative (9) & $5(55.6 \%)$ & $2(22.2 \%)$ & $4(44.4 \%)$ & $2(22.2 \%)$ \\
\hline \multirow[t]{2}{*}{ Positive (19) } & $10(52.6 \%)$ & $3(15.8 \%)$ & $10(52.6 \%)$ & $9(47.4 \%)$ \\
\hline & $\mathrm{P}=0.885$ & $\mathrm{p}=0.678$ & $\mathrm{p}=0.686$ & $\mathrm{p}=0.203$ \\
\hline \multicolumn{5}{|c|}{ High blood pressure } \\
\hline Negative (20) & $9(45 \%)$ & $3(15 \%)$ & $8(40 \%)$ & $4(20 \%)$ \\
\hline \multirow[t]{2}{*}{ Positive (8) } & $6(75 \%)$ & $2(25 \%)$ & $6(75 \%)$ & $2(25 \%)$ \\
\hline & $\mathrm{P}=0.150$ & $\mathrm{p}=0.533$ & $\mathrm{p}=0.094$ & $\mathrm{p}=0.771$ \\
\hline \multicolumn{5}{|l|}{ Menstrual disorder } \\
\hline Negative (25) & $20(80 \%)$ & $6(24 \%)$ & $15(60 \%)$ & $6(24 \%)$ \\
\hline \multirow[t]{2}{*}{ Positive (3) } & $3(100 \%)$ & $2(66.7 \%)$ & $2(66.7 \%)$ & $1(333 \%)$ \\
\hline & $\mathrm{p}=0.393$ & $\mathrm{p}=0.122$ & $\mathrm{p}=0.823$ & $\mathrm{p}=0.724$ \\
\hline
\end{tabular}

in blood and bodily fluids, furthermore, the availability of patients' blood is more convenient compared to tumor tissues (Nagrath et al., 2007; Sharma et al., 2007). For this study, both blood and tissue samples were selected. Hemi-methylated promoter regions of PTEN was $88.46 \%$ in patients' blood, $46.43 \%$ in tumor tissues and methylated regions were $11.54 \%$ and $28.57 \%$ in patients' blood and tumor tissues, respectively. The results indicated that the frequency of hemi-methylated regions was higher than methylated regions. Our findings support a significant difference in the promoter methylation of the PTEN gene in the patients' blood and normal tissues $(\mathrm{p}=0.0353)$. In contrast, the methylated promoter region of $A P C$ was $3.85 \%$ and $17.86 \%$ in patients' blood and tumor tissues, respectively and no significant difference was observed in patients' blood ( $p=0.0623$ ) and tumor tissues $(p=0.4296)$. This discrepancy might be due to environmental effects and sample size. PTEN promoter hypermethylation is a broadly studied genetic mutation in endometrial cancer (Salvesen et al., 2001). Gao et al., (2009) reported that the expression of $P T E N$ has decreased during the progression of endometrial cancer $(\mathrm{P}<0.01)$. They showed that PTEN expression is correlated to the tumor stage, tumor grade, and histologic type $(\mathrm{P}<0.05)$, but there was no significant difference in the depth of myometrial invasion $(\mathrm{P}>0.05)$. In our study, we observed a significant increase in the hypermethylation of PTEN in patients' blood. We found no relationship between clinicopathological features and endometrial cancer. Zuberi et al., (2014) showed that the frequency of PTEN promoter hypermethylation was $16 \%$ in the blood of patients with ovarian cancer and there was no significant difference in the PTEN methylation of the promoter between patients and controls $(\mathrm{p}=0.09)$. They found no significant correlations between clinicopathological features, including age, tumor stage, and histologic type, and patients type $(\mathrm{P}>0.05)$.
In our estimate, the prevalence of PTEN methylation was $11.54 \%$ and $28.57 \%$ in patients' blood and tumor tissues, respectively. QI et al., (2014) showed that the frequency of PTEN promoter hypermethylation was $62 \%$ in tumor tissues of patients with cervical cancer where the methylation of the PTEN promoter was significantly related to the tumor grade, metastasis, and tumor stage $(\mathrm{P}<0.05)$. They found a significant association between the promoter methylation of PTEN and cervical cancer $(\mathrm{P}=0.042)$. They also suggested that promoter hypermethylation could be a key mechanism of PTEN inactivation in cervical cancer. We found a meaningful association between the hypermethylation of the PTEN promoter and endometrial cancer in patients' blood. The $A P C / \beta$-catenin pathways were initially reported in the field of endometrial cancer (Aoki and Taketo, 2007; Moreno-Bueno et al., 2002). Guo et al., (2014) reported a significant association between the $A P C$ promoter methylation and non-small cell lung cancer (NSCLC) $(\mathrm{OR}=3.79,95 \%$ CI [2.22 - 6.45], $\mathrm{P}<0.0001)$. According to Ignatov (2010), 56.9\% of endometrial carcinomas show $A P C$ promoter methylation in tumor tissues. They revealed that there was no relationship between histological type, histological grading, and methylation of the $A P C$ gene. However, there was a significant reverse relationship between metastasis and $A P C$ methylation $(\mathrm{p}=0.002)$. In our study, promoter methylation in the $A P C$ gene was found in $3.85 \%$ and $17.86 \%$ of patients' blood and tumor tissues, respectively. Richiardi (2009), reported that $A P C$ hypermethylation had an important role in prostate cancer and there was a significant association between prostate cancer and $A P C$ promoter hypermethylation ( $\mathrm{OR}=1.49,95 \%$ CI [ 1.11 to 2.00$], \mathrm{P}=0.047$ ). Our results closely linked a statistically significant difference in the promoter methylation analysis of the $A P C$ gene between tumor tissues and patients' blood. Moreover, we found 
no significant relationship between clinicopathological features and $A P C$ methylation $(\mathrm{P}>0.05)$. Based on our study, promoter hypermethylation of $A P C$ and PTEN genes may be a biomarker in the diagnosis of endometrial cancer. More studies with larger populations and a suitable election of the case-control study will be essential to understand the role of hypermethylation of the $A P C$ and $P T E N$ genes as biomarkers in endometrial cancer.

In conclusion, promoter methylation of tumor-suppressor genes is a typical epigenetic change in endometrial cancer. Hypermethylation of PTEN and APC in the promoter region may have a significant effect in the development of endometrial cancer. In our study, there was a significant relationship between blood and tissue in PTEN methylation $(\mathrm{OR}=2.4377,95 \%$ CI [1.0635-5.5876], $\mathrm{p}=0.0353)$. However, there was no evidence to support an association of promoter methylation of the $A P C$ gene in tumor tissues with endometrial cancer $(\mathrm{OR}=0.7073,95 \%$ CI [0.2995-1.6703], $\mathrm{p}=0.4296)$. Furthermore, there was a closely significant difference between the methylated regions in blood and tissue samples of the $A P C$ gene as well as normal tissue and tumor tissue of the PTEN gene $(\mathrm{OR}=0.4047,95 \%$ CI $[0.1563-1.0476], \mathrm{p}=0.0623)$; $(\mathrm{OR}=2.0765,95 \%$ CI [0.9197-4.6887], $\mathrm{p}=0.0787)$, respectively.

\section{Acknowledgements}

This work was supported by the Biology Research Center of Islamic Azad University, Zanjan (Iran).

\section{Funding}

This research was not supported by any specific grants from funding agencies in the public, commercial, or notfor-profit sectors.

\section{Conflict of Interest}

The authors declare no conflict of interest.

\section{References}

Aoki K, Taketo MM (2007). Adenomatous polyposis coli (APC): a multi-functional tumor suppressor gene. J Cell Sci, 120, 3327-35.

Banno K, Yanokura M, Iida M, Masuda K, Aoki D (2014). Carcinogenic mechanisms of endometrial cancer: involvement of genetics and epigenetics. JObstet Gynaecol Res, 40, 1957-67.

Banno K, Yanokura M, Susumu N, et al (2006). Relationship of the aberrant DNA hypermethylation of cancer-related genes with carcinogenesis of endometrial cancer. Oncol Rep, 16, 1189-96.

Behrens J, von Kries JP, Kühl M, et al (1996). Functional interaction of beta-catenin with the transcription factor LEF-1. Nature, 382, 638-42.

Creasman WT, Odicino F, Maisonneuve P, et al (2006). Carcinoma of the corpus uteri.FIGO 26th annual report on the results of treatment in gynecological cancer. Int $J$ Gynaecol Obstet, 95, 105-43.

Dubrovska A, Kim S, Salamone RJ, et al (2009). The role of $P T E N / A k t / P I 3 K$ signaling in the maintenance and viability of prostate cancer stem-like cell populations. Proc Natl Acad Sci U S A, 106, 268-73.
Fearnhead NS, Britton MP, Bodmer WF (2001). The ABC of APC. Hum Mol Genet, 10, 721-33.

Feng ZZ, Chen JW, Yang ZR, Lu GZ, Cai ZG (2012). Expression of PTTG1 and PTEN in endometrial carcinoma: correlation with tumorigenesis and progression. Med Oncol, 29, 304-10.

Gao Q, Ye F, Xia X, et al (2009). Correlation between PTEN expression and PI3K/Akt signal pathway in endometrial carcinoma. J Huazhong Univ Sci Technol Med Sci, 29, 59-63.

Gravina S, Ganapathi S, Vijg J (2015). Single-cell, locus-specific bisulfite sequencing (SLBS) for direct detection of epimutations in DNA methylation patterns. Nucleic Acids Res, 43, 93.

Guo S, Tan L, Pu W, et al (2014). Quantitative assessment of the diagnostic role of $A P C$ promoter methylation in non-small cell lung cancer. Clin Epigenetics, 6, 5.

Herman JG, Baylin SB (2003). Gene silencing in cancer in association with promoter hypermethylation. $N$ Engl J Med, 349, 2042-54.

Ignatov A, Bischoff J, Ignatov T, et al (2010). APC promoter hypermethylation is an early event in endometrial tumorigenesis. Cancer Sci, 101, 321-7.

Kobayashi K, Sagae S, Nishioka Y, Tokino T, Kudo R (1999). Mutations of the beta-catenin gene in endometrial carcinomas. Jpn J Cancer Res, 90, 55-9.

Kong D, Suzuki A, Zou TT, et al (1997). PTEN1 is frequently mutated in primary endometrial carcinomas. Nat Genet, 17, 143-4.

Laird PW (2003). The power and the promise of DNA methylation markers. Nat Rev Cancer, 3, 253-66.

Macdonald ND, Salvesen HB, Ryan A, et al (2004). Molecular differences between RER+ and RER- sporadic endometrial carcinomas in a large population-based series. Int J Gynecol Cancer, 14, 957-65.

Markowska A, Pawałowska M, Lubin J, Markowska J (2014). Signalling pathways in endometrial cancer. Contemp Oncol (Pozn), 18, 143-8.

Moreno-Bueno G, Hardisson D, Sánchez C, et al (2002). Abnormalities of the $A P C /$ beta-catenin pathway in endometrial cancer. Oncogene, 21, 7981-90.

Muraki Y, Banno K, Yanokura M, et al (2009). Epigenetic DNA hypermethylation: clinical applications in endometrial cancer (Review). Oncol Rep, 22, 967-72.

Mutter GL, Boynton KA, Faquin WC, Ruiz RE, Jovanovic AS (1996). Allelotype mapping of unstable microsatellites establishes direct lineage continuity between endometrial precancers and cancer. Cancer Res, 56, 4483-6.

Nagase H, Nakamura Y (1993). Mutations of the APC (adenomatous polyposis coli) gene. Hum Mutat, 2, 425-34.

Nagrath S, Sequist LV, Maheswaran S, et al (2007). Isolation of rare circulating tumour cells in cancer patients by microchip technology. Nature, 450, 1235-9.

Oda K, Stokoe D, Taketani Y, McCormick F (2005). High frequency of coexistent mutations of PIK3CA and PTEN genes in endometrial carcinoma. Cancer Res, 65, 10669-73.

Powell SM, Zilz N, Beazer-Barclay Y, et al (1992). APC mutations occur early during colorectal tumorigenesis. Nature, 359, 235-7.

Qi Q, Ling Y, Zhu M, et al (2014). Promoter region methylation and loss of protein expression of PTEN and significance in cervical cancer. Biomed Rep, 2, 653-8.

Richiardi L, Fiano V, Vizzini L, et al (2009). Promoter methylation in $A P C$, RUNX3, and GSTP1 and mortality in prostate cancer patients. J Clin Oncol, 27, 3161-8.

Risinger JI, Hayes AK, Berchuck A, Barrett JC (1997). PTEN/ MMAC1 mutations in endometrial cancers. Cancer Res, 57, 4736-8.

Rychahou PG, Kang J, Gulhati P, et al (2008). Akt2 overexpression 
plays a critical role in the establishment of colorectal cancer metastasis. Proc Natl Acad Sci U S A, 105, 20315-20.

Salvesen HB, MacDonald N, Ryan A, et al (2001). PTEN methylation is associated with advanced stage and microsatellite instability in endometrial carcinoma. Int $J$ Cancer, 91, 22-6.

Schlosshauer PW, Pirog EC, Levine RL, Ellenson LH (2000). Mutational analysis of the CTNNB1 and $A P C$ genes in uterine endometrioid carcinoma. Mod Pathol, 13, 1066-71.

Sharma G, Mirza S, Prasad CP, et al (2007). Promoter hypermethylation of p16INK4A, p14ARF, CyclinD2 and Slit2 in serum and tumor DNA from breast cancer patients. Life Sci, 80, 1873-81.

Tao MH, Freudenheim JL (2010). DNA methylation in endometrial cancer. Epigenetics, 5, 491-8.

Trimble EL, Harlan LC, Clegg LX, Stevens JL (2005). Pre-operative imaging, surgery and adjuvant therapy for women diagnosed with cancer of the corpus uteri in community practice in the United States. Gynecol Oncol, 96, 741-8.

Velasco A, Bussaglia E, Pallares J, et al (2006). PIK3CA gene mutations in endometrial carcinoma: correlation with PTEN and K-RAS alterations. Hum Pathol, 37, 1465-72.

Waite KA, Eng C (2002). Protean PTEN: form and function. Am J Hum Genet, 70, 829-4.

Yang HJ, Liu VW, Wang Y, Tsang PC, Ngan HY (2006). Differential DNA methylation profiles in gynecological cancers and correlation with clinico-pathological data. $B M C$ Cancer, 6, 212.

Yari M, Movafagh A, Sayad A, et al (2016). Direct bisulfite sequencing and methylation specific PCR to detect methylation of p15INK4b and F7 genes in coronary artery disease patients. $J$ Sci I R Iran, 27, 23-9.

Zhang S, Yu D (2010). PI(3)king apart PTEN's role in cancer. Clin Cancer Res, 16, 4325-30.

Zuberi M, Mir R, Dholariya S, et al (2014). RASSF1 and $P T E N$ promoter hypermethylation influences the outcome in epithelial ovarian cancer. Clin Ovarian Gynecol Cancer, 7, 33-9.

\section{cc) (7) (8)}

This work is licensed under a Creative Commons AttributionNon Commercial 4.0 International License. 